\title{
The Enlightenment to China from UK's Pension Entering Capital Market
}

\author{
Yuting Liu, Qingjun Meng, Yong Ma \\ Business School in Hohai University, Nanjing, China \\ Email: alwayswand@163.com
}

Received 1 August 2016; accepted 26 August 2016; published 29 August 2016

Copyright (C) 2016 by authors and Scientific Research Publishing Inc.

This work is licensed under the Creative Commons Attribution International License (CC BY). http://creativecommons.org/licenses/by/4.0/

c) (i) Open Access

\begin{abstract}
As the aging problem is increasingly serious in China, the pension operation and management attract more and more attentions. However, China's pension yields have been low, leaving a lot of problems. There are growing calls to make China's pension enter capital market. While, there exists many risks, such as the unavoidable stock market risk and the potential risk in the "principal-agent". Pension management should be of caution and safety. Attentions should be paid to improve relevant laws, strengthen supervision, perfect China's multi-pillar pension system and so on. UK has enlightened China on pension entering capital market.
\end{abstract}

\section{Keywords}

Aging Population, Pension Insurance Fund, Capital Market, Asset Allocation

\section{Introduction}

Aging population is one of the most important demographic behaviors and social phenomena in current China. The 6th national population census in 2010 showed that there are about 177.65 million people aged 60 and above, accounting for $13.26 \%$ of the total population. The data from a press conference about human resources and social security work progress in the second quarter of 2016 showed that, by the end of 2015, people aged 60 and above reached 220 million, accounting for $16.1 \%$ of the total population. The world Health Organization (WHO) predicts that by 2050, there will be 35\% population over 60 years old in China and China will become a country who is most affected by aging.

From 2009 to 2014, the average annual investment yield on pension rose on the whole, while compared with China's inflation rate over the past few years, it can be found that pension, against the background of inflation in our country, faces pressure on maintaining and increasing the value, and a large scale of depreciation. Meanwhile, the national social security yield was significantly higher. The reason is that the investment ways of social 
security fund are much richer than those of the endowment insurance fund, and it also allows for a certain amount of investment to "enter the capital market". Therefore, in order to solve these problems including low yields, single ways of investment, investment type and limited channel, a market-oriented reform on pension investment should be conducted and to maintain and increase is particularly crucial (Table 1) [1]. The "Basic Management Approach of Pension Insurance Fund Investment" issued by the State Council in August 2015 marked that the pension to enter the capital market was formally on the agenda. China has picked up its pace in making pension into the market.

\section{Relevant Research}

Xiong Jun (2009) argued that asset allocation was an important part of the pension funds management because there is no absolute optimal single asset in the world [2]. Zheng Bingwen and Sun Shouji, in Development Process of British Occupational Pension Regulatory System, gave a detailed analysis of the main characteristics, the key problems and the solutions of each stage of British pension regulatory system. In the end, this paper pointed out that the practical experience of British occupational pension regulatory system had a extremely reference significance for China [3]. In Experience and Reference of Supervision of British Pension Investing Stock Market, Yang Yansui proposed that governing pension market according to the law and ensuring safe operation of the pension plan is the core issue of reform of retirement pension system in our country [4]. Hu Jiye argued that British pension system was mainly composed of national pension, occupational pension and private pension. And in addition to the first pillar, others preserved or increased the value by investing in the capital market [5]. Wei Xiumin thought that Britain actively explored market-oriented reform of the pension under double pressures of aged tendency of population and the economic decline. And it can not only reduce the government's financial burden and improve the flexibility of the Labour market, but also increase the household saving rate through reform. So the reform of endowment insurance in our country can refer to the ideas of Britain's reform, then redefine the responsibilities of government to market and government to enterprise and give full play to the enthusiasm of individual insurance and individual pension savings rate to promote the macroeconomy [6].

$\mathrm{Li}, \mathrm{X}$. Q. (2009) analyzed the pension investment operation and gave some detailed advice about investing multi-method fund and the enhancing its supervision are provided [7]. Jiang, L. N. (2013) "The Risk and Its Countermeasures for China's Pension into the Market" showed "the basic theory of pension-operation and investment risk management to analyze the necessity of pension market and market-risk, then analyzes measures of pension management and regulatory risk, and the existing problems, and learn from foreign experience, on this basis, summed up the conclusions of this study and put forward targeted policy recommendations” [8].

\section{Potential Risk for Pension into Market}

\subsection{Unavoidable Risk of Stock Market}

The pension "entering capital market" not only can produce higher yields, but also risks. The capital markets, especially the stock market, are not stable, so it is impossible for the pension market to keep earning instead of losing forever. Even though the capital markets like the United Kingdom and the United States boast long development histories which are relatively mature and developed, they were stricken by the financial crisis in 2008.

Table 1. Yield rates of pension insurance fund and social insurance, and inflation rates from 2009 to 2014.

\begin{tabular}{cccc}
\hline Year & Pension insurance fund (\%) & Social insurance (\%) & Inflation (\%) \\
\hline 2009 & 2.2 & 16.12 & -0.70 \\
2010 & 2.0 & 4.23 & 3.30 \\
2011 & 2.5 & 5.58 & 5.40 \\
2012 & 2.6 & 7.01 & 2.60 \\
2013 & 2.4 & 6.20 & 2.60 \\
2014 & 2.9 & 11.69 & 2.42 \\
\hline
\end{tabular}

Source: National Bureau of Statistics, Annual Report of China's Social Insurance Development, etc. 
The UK stock market once shrank seriously. It has led to a loss of 15 billion pounds (about 150 billion Yuan) in pension fund within one year, dissatisfying UK public. However, China has only twenty years of capital market development. The reform and development as China has undergone, its system and laws are still incomplete. There insider trading and being the banker and alike have left challenges for the pension into the capital market. In addition, China differs from western countries in terms of capital market. The capital market in our country is mainly composed of retail investors and few institutional investors. During 17 trading days from June 15 to July 8, 2015, the Shanghai Composite Index fell 32\%. Just in 11 months, the stock market experienced big bubble and crash in 2015. It will leave great pressure for pension value.

\subsection{Possible Risks in "Principal-Agent"}

If the pension enters into the market, some principal-agent relationship will be produced in the investment operation process. When the pension management institutions entrusted fund corporations or other institutions to engage in the pension investment operations, a principal-agent relationship between the two is formed. The pension management institutions are the principals, and fund corporations or the national social security fund council are the agents. However, according to the explanation of economics, in the principal-agent relationship, the principal is always the uninformed for information and the agent is the information insider because the agent, as information insider, will affect the interests of the client which means that the client need to bear the risk caused by agent's behavior [1].

\section{The Enlightenment to China on UK's Pension into the Market}

\subsection{Complete Relevant Laws and Strengthen Supervision}

The normative laws and reform measures with legal effect have contributed a lot in UK's pension marketizing. The pension management agency established according to the Endowment Security Law of 1995 is responsible for the supervision of pension fund trust, in order to prevent misgovernment and deception in the pension market; The department shall have the right to conduct qualification review and identification on the trustee; The agency also has been granted certain right of jurisdiction, and can directly impose punishment on trustees and relevant institutions for breaching duty; even, in order to protect the interests of the beneficiary, the pension management agency shall have the right to terminate a pension plan or replace it by another program according to the request of the employer or the trustee. Although the development of capital market in China has reached 20 years, and the laws and regulations are relatively perfect, there is still a long way to go when compared with the western developed countries. Therefore, on the one hand, the government should give play to the role of the legal regulations, complete China's capital market laws and regulations system, regularize the behaviors of main investment body, the fund management companies and the listed companies, and avoid speculation caused by exploiting law loopholes. On the other hand, the supervision should be enhanced, the information disclosure should be strengthened, and the shady deals caused by manipulation should be reduced. The government should intensify the administrative penalties of speculation and formulate policies related to economic compensation, providing a fair and sound trade environment for the pension market.

\subsection{Define Government's Responsibilities in Pension}

Both the pension marketization reform in UK and the reform of "social-personal" model of endowment insurance are dominated by their own governments. The two governments play a dominant role in their pension system change. With the growing aging population and economic globalization, the original pay-as-you-go mode of endowment insurance system in the world has brought a lot of pressure to national finance. The UK government has shifted from a "leading responsible one" to a "moderately responsible one" after nearly 30 years of pension reform. The government has gradually faded out from the pension programs, completing a role transformation successfully. The Chinese government also should gradually fades out from their pension status, to leave it more managed by independent agency. In addition, the government may establish a pension management department, and give it greater independence and make it coordinate with financial regulatory institutions (e.g., the China banking regulatory commission, insurance regulatory commission and the securities and futures commission) dealing pension business [4]. Conduct supervision on the special requirements of pensions into the market which is different from other funds. 


\subsection{Improve the Multi-Pillar Pension System in China}

UK has eventually established a relatively perfect three-pillar pension system. The first pillar is the national basic endowment insurance geared to the national citizens, the second pillar is occupational pension for the employees, and the third pillar is voluntary endowment insurance of fund accumulation system. Qualified citizens can choose pension plans which suit themselves in accordance with actual conditions. China has started building the multi-pillar pension system since 1997. Although this has already formed a basic framework, each pillar has imbalanced development problems. Its coverage is so narrow that the multi-pillar pension system is still in the stage of underdevelopment. China shares some similarity with UK with regard to the multi-pillar pension mode, but the two kinds of endowment models have substantive differences. The three pillars of UK pension system were independent of each other, and connect with each other to a certain extent, so that citizens have great freedom of making choice. Nevertheless, China's first and second pillars are in the stage of social-personal combination that they are not independent enough. The third and fourth pillars perform practically no function. Their slow development is unable to achieve the unexpected effects. With reference to UK's experience, China can gradually shift from partially-funded system featured by "collection of inflation, shambolic management and empty account operation" to multi-pillar pension system including basic pension system, individual account pension system, voluntary occupational pension system and individual deposit insurance [9].

\subsection{Improve China’s Capital Market System}

China's capital market is based on retail investors, which differs from UK greatly. Therefore, China sees more ups and downs in capital market, and is also more vulnerable to manipulation. Before the pension enters into the market, therefore, China's capital market system should be improved, and the capital investment environment should be enhanced. Strengthen the performance auditing of the listed company, ensure prudent operation of market main body, and further propel the reform of initial public offering (IPO) system. Meanwhile, strengthen the market supervision and punishment on speculative behaviors including insider trading and market hype, formulate relevant compensation policy, ensure a rationally developed capital market, and reduce the risk of the pension market. In addition, the market will become more stable when the pension enters into the market. Hence, the securities supervision department should seize the opportunity and reorganize the securities market in China. The securities market in our country is single in structure, for instance, few varieties of bonds. Besides, the financial innovation products in China's capital market are not rich, so it can increase the financial innovation products and market investments via this opportunity.

\subsection{The Principal-Agent Mechanism Conforms to China's Conditions}

In the UK, the pension fund trustees boast more investment options with the purpose to maximize the interests of the beneficiary in the portfolio investment. Pension fund trustees, therefore, are free from the restrictions of investment type. This makes the UK pension fund investment more flexible. However, pension fund trustees' capital authority should be appropriately reduced and controlled in the initial stage. Strict rules and regulations should be enacted because China has little experience of capital operation in the infant stage even though China's pension balance is relatively small to the scale of the stock market. Therefore, it is suggested that the inner capital market choose to be passive investment of funds so as to reduce the agency problems and risks of asymmetric information. This rule can be gradually let go in the future and give pension fund trustees more investment options like the UK does.

\section{Conclusion}

Based on the current aging condition and low pension yields in China, it is of great necessity for the pension into the capital market, regardless of capital market risk and principal-agent risk. We should learn lessons from the UK and other countries, improve the external environment and solve the internal problems, and expedite China's pension into the market. It is estimated that China's pension into the market will be implemented within two or three years. It will relieve the pressure on China's aging population and keep benign interactions with the capital market. In addition, it will provide much financing for listed companies to keep the stock market maintain vitality, etc. 


\section{References}

[1] Li, Y.J. (2016) China’s Pension into the Market: Is It a Rational Policy or an Interest Game?-An Analysis on Pension into the Market and Management Mechanism from the Perspectives of "Principal-Agent". Contemporary Economic Management, No. 5, 93-90.

[2] Xiong, J. and Qiu, H. (2009) The Main Types and Functions of Pension Fund Asset Allocation. State Assets Management, No. 8, 57-58.

[3] Zhang, B.W. and Sun, S.J. (2008) The Development of Occupational Pension Regulatory System in the UK. Chinese Journal of European Studies, No. 2, 121-136.

[4] Yang, Y.S. (2003) UK’s Experience and Reference in Pension into the Market Supervision. Shanghai Finance, No. 8, 36-37.

[5] Hu, J.Y. (2011) The Change of Pension System in Rich Countries: A Case Study of the United Kingdom. International Economic Review, No. 6, 112-122.

[6] Wei, X.M. (2007) The Market-Oriented Reform of Endowment Insurance in UK and Its Revelation to China. Journal of Tianjin Vocational Institutes, No. 1, 21-25.

[7] Li, X.Q. (2009) The Investment Operation Analysis on China’s Pension Insurance Fund. Special Zone Economy, No. 9, 208-210.

[8] Jiang, L.N. (2013) The Risk and Its Countermeasures for China’s Pension into the Market. Northeast Normal University, Master of Finance.

[9] Yang, L.L. (2014) The Pension System and Market Reform of UK under the Background of the Debt Crisis. Nanjing University, Master of Social Security.

\section{Submit or recommend next manuscript to SCIRP and we will provide best service for you:}

Accepting pre-submission inquiries through Email, Facebook, LinkedIn, Twitter, etc.

A wide selection of journals (inclusive of 9 subjects, more than 200 journals)

Providing 24-hour high-quality service

User-friendly online submission system

Fair and swift peer-review system

Efficient typesetting and proofreading procedure

Display of the result of downloads and visits, as well as the number of cited articles

Maximum dissemination of your research work

Submit your manuscript at: http://papersubmission.scirp.org/ 